\title{
Population structure of a predatory beetle: the importance of gene flow for intertrophic level interactions
}

\author{
MOSHE COLL*, LAURA GARCIA DE MENDOZA \& GEORGE K. RODERICK† \\ Department of Entomology, University of Maryland, College Park, MD 20742, U.S.A.
}

\begin{abstract}
Migration and gene flow of natural enemies play an important role in the stability of predator-prey interactions and community organization in both natural and managed systems. Yet, relative to that of their herbivorous insect prey, the genetic structure of natural enemy populations has been little studied. We present evidence that populations of the predatory coccinellid beetle Coleomegilla maculata (Coleoptera: Coccinellidae), are not genetically subdivided and that levels of gene flow among these populations are extremely high. Furthermore, in the same geographical area, gene flow of $C$. maculata was significantly (one order of magnitude) greater than that of an abundant prey species, the Colorado potato beetle Leptinotarsa decemlineata (Coleoptera: Chrysomelidae). The high mobility of this natural enemy relative to the insect herbivores on which it feeds may contribute to its effectiveness as a biological control agent in agricultural systems.
\end{abstract}

Keywords: allozyme, biological control, electrophoresis, gene flow, metapopulation, natural enemies.

\section{Introduction}

The genetic structure of populations is a function of their spatial arrangement and amount of gene flow among them. The extent of gene flow will determine not only the potential for populations to diverge genetically but will also influence local population dynamics. For predatory species, these effects are also likely to be coupled with the dynamics and movement of their prey. The association between predator and prey is well illustrated, theoretically and experimentally, by predators and parasitoids (collectively termed natural enemies) and the herbivorous insects which they attack. For example, movement of natural enemies may contribute to their aggregative response to sites harbouring varying numbers of prey (Murdoch et al., 1985; Strong, 1988). Under some conditions, such aggregative response by natural enemies may have, at least theoretically, stabilizing effects on populations (Hassell, 1978; Hassell \& May, 1988) or metapopulations (Taylor, 1991) of predators and prey.

*Correspondence: USDA, ARS, Insect Biocontrol Laboratory, BARC-East, BIdg. 402, Beltsville, MD 20705, U.S.A.

$\uparrow$ Present address: Hawaiian Evolutionary Biology Program, University of Hawaii, 3050 Maile Way Gilmore 310, Honolulu, HI 96822, U.S.A.
Despite the recognized importance of mobility of natural enemies, little is known about their population structure, especially the amount of gene flow (Roderick, 1992) and dispersal (Coll, 1991) among field populations. This lack of information stands in contrast to the studies of the genetic structure of herbivorous insect populations in both natural (Slatkin, 1985a, 1987; McCauley \& Eanes, 1987) and managed systems (Loxdale \& den Hollander, 1989; Roderick \& Caldwell, 1992).

Many studies have examined the role gene flow plays in the development of local adaptation in herbivores, including the evolution of host races (Butlin, 1990; Roderick, 1993) and the development of insecticide resistance in pest species (Comins, 1977; Georghiou \& Taylor, 1977; Taylor \& Georghiou, 1979; Tabashnik \& Croft, 1982; Caprio \& Tabashnik, 1992b). Selection pressure from pesticide application will also affect natural enemies (Rosenheim \& Hoy, 1986; Rosenheim \& Tabashnik, 1991). In general, low levels of gene flow may permit local adaptations such as the evolution of insecticide resistance (Caprio \& Tabashnik, 1992b). If natural enemies are indeed more mobile than their hosts or prey (Murdoch et al., 1985) then natural enemies may not develop insecticide resistance as rapidly as their herbivorous prey. In turn, differences in susceptibility to insecticides between herbivores and natural enemies may facilitate pest out- 
breaks and resurgence because of the removal of predators and parasites by pesticide applications. It is unclear, however, how differences in gene flow between natural enemies and their herbivorous prey affect their susceptibility to insecticides.

Two approaches are commonly used to estimate gene flow among populations: direct measures, such as release-recapture, and indirect estimates based on patterns of genetic similarity among populations (Slatkin, 1985a, 1987). Although direct measures of dispersal represent actual observations, they may be biased by not reflecting rare gene flow events or non-random contributions to subsequent generations (Ehrlich \& Raven, 1969; Endler, 1979; Slatkin, 1987). By contrast, indirect estimates of gene flow, based on $F_{\mathrm{ST}}$ (Wright, 1951) or rare alleles (Slatkin \& Barton, 1989), reflect variations in allele distribution that were produced over long periods (Slatkin, 1987; McCauley, 1991).

In this study, we first used allozyme electrophoresis to examine the population structure of a predatory beetle, Coleomegilla maculata De Geer (Coleoptera: Coccinellidae). Then, we tested the hypothesis that level of gene flow among populations of this predator is greater than that among populations of one of its sympatric abundant prey species, the Colorado potato beetle, Leptinotarsa decemlineata Say (Coleoptera: Chrysomelidae).

\section{Methods}

\section{Biological material}

The predatory beetle C. maculata is native to North America and is widely distributed east of the Rocky Mountains (Obrycki \& Tauber, 1978). In both natural and managed systems, larvae and adults are important natural enemies of aphids, insect eggs and soft-bodied immatures (Smith, 1960; Atallah \& Newsom, 1966; Warren \& Tadic, 1967, and references therein). The predator is common in maize, alfalfa, cotton, potato, tobacco, curcubits and cole crop systems (Ewert \& Chiang, 1966; Richardson \& DeLoach, 1973; Elsey, 1974; Wright \& Laing, 1980; Marck \& Smilowitz, 1982; Cosper et al., 1983; Groden et al., 1990; Coll \& Bottrell, 1991; Hazzard et al., 1991). In potatoes, $C$. maculata can be a major natural enemy of the Colorado potato beetle (Groden et al., 1990; Hazzard \& Ferro, 1991; Hazzard et al., 1991).

Six populations of overwintering adult $C$. maculata were sampled in Maryland, U.S.A., between $31 \mathrm{March}$ and 10 April 1992 (Fig. 1). The sampling sites were in the following counties: Washington $\left(39^{\circ} 30^{\prime} 55^{\prime \prime} \mathrm{N}\right.$; $\left.77^{\circ} 44^{\prime} 50^{\prime \prime} \mathrm{W}\right)$, Frederick $\left(39^{\circ} 16^{\prime} 05^{\prime \prime} \mathrm{N} ; 77^{\circ} 28^{\prime} 05^{\prime \prime} \mathrm{W}\right)$, Montgomery $\left(39^{\circ} 17^{\prime} 30^{\prime \prime} \mathrm{N}\right.$; $\left.77^{\circ} 12^{\prime} 25^{\prime \prime} \mathrm{W}\right)$, Howard $\left(39^{\circ} 12^{\prime} 45^{\prime \prime} \mathrm{N} ; \quad 76^{\circ} 56^{\prime} 10^{\prime \prime} \mathrm{W}\right), \quad$ Prince George
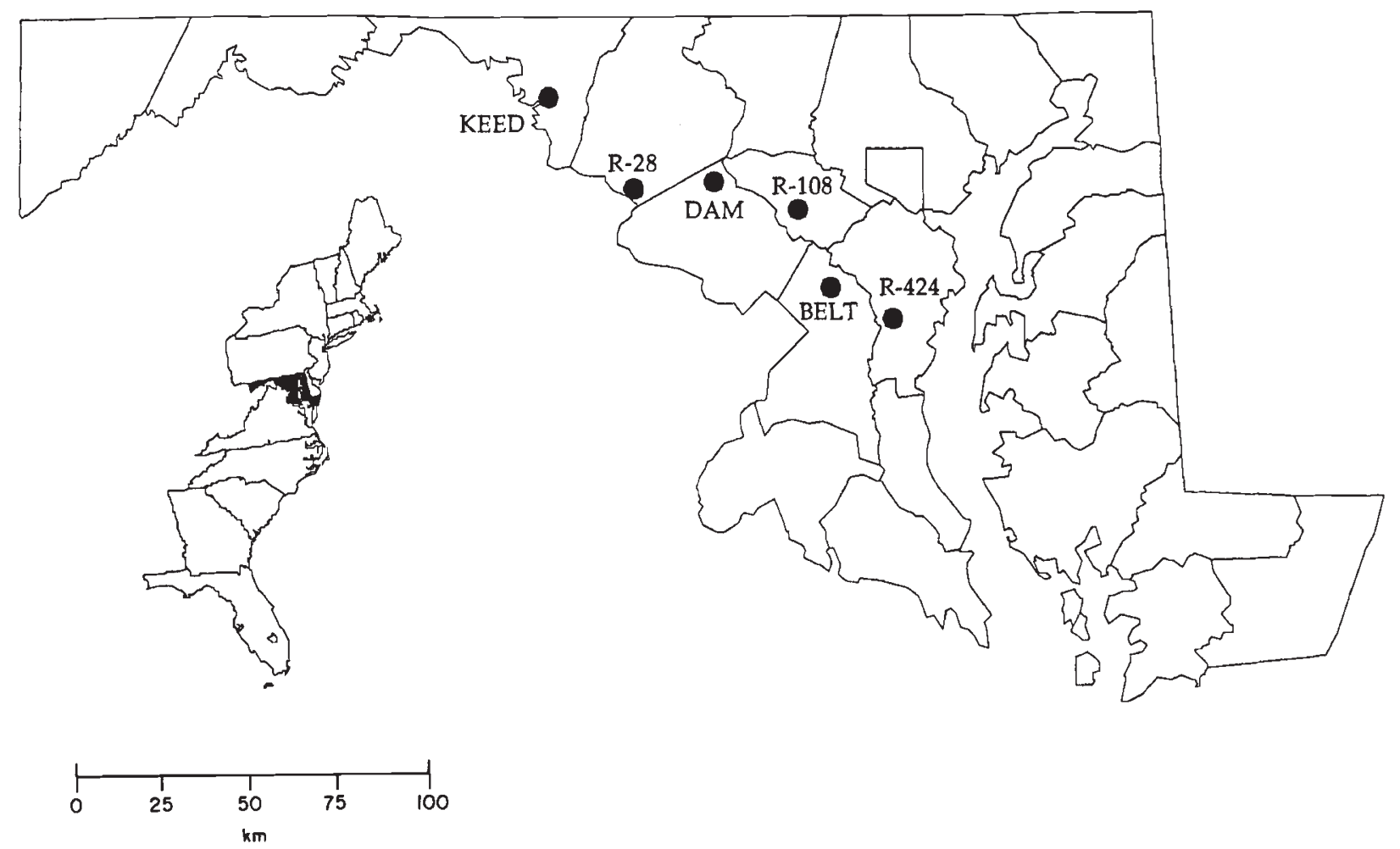

Fig. 1 Collection sites of six Coleomegilla maculata overwintering aggregations in Maryland, U.S.A. 
$\left(39^{\circ} 00^{\prime} 40^{\prime \prime} \mathrm{N} ; 76^{\circ} 49^{\prime} 55^{\prime \prime} \mathrm{W}\right)$ and Anne Arrundel $\left(38^{\circ} 55^{\prime} 50^{\prime \prime} \mathrm{N} ; 76^{\circ} 37^{\prime} 45^{\prime \prime} \mathrm{W}\right)$. The approximate distance between the westernmost and the easternmost populations was $116 \mathrm{~km}$. The beetles were collected from overwintering aggregations at the base of prominent trees at the edge of maize fields. Since $C$. maculata does not exhibit a long distance migratory behaviour to overwintering sites (Hagen, 1962), all beetles collected from the same aggregation are considered to belong to the same population or random breeding unit. The beetles were maintained in the laboratory $\left(25 \pm 3^{\circ} \mathrm{C}\right.$; 15:9 L:D) until they were no longer in diapause (determined by flight and feeding behaviours) and after any parasitoids (Dinocampus (= Perilitus) coccinellae (Hymenoptera: Braconidae)) had emerged (about 25 April). The beetles were frozen at $-80^{\circ} \mathrm{C}$ until preparation for electrophoresis.

\section{Electrophoresis}

Cellulose-acetate gels (Helena Laboratories Inc.) were used for electrophoresis (Richardson et al., 1986; Hebert \& Beaton, 1989). Before electrophoresis, beetles were homogenized individually in $50 \mu \mathrm{l}$ of distilled water and centrifuged for $5 \mathrm{~min}$ at $4^{\circ} \mathrm{C}$. Resolving gels were maintained at $4^{\circ} \mathrm{C}$ during electrophoresis. A preliminary survey of 17 enzyme systems revealed nine polymorphic resolvable loci. The following seven enzyme systems encoded by nine presumptive loci were scored in all six populations: fumarate hydratase $(F U M)$; isocitrate dehydrogenase ( $I D H$, two loci: fast $[f]$ and slow $[s])$; malate dehydrogenase $(M D H$, two loci: $[f$ and $s]) ;$ peptidase (PEP); 6-phosphogluconate dehydrogenase $(6 P G D H)$; phosphoglucose isomerase $(P G I)$ and phosphoglucomutase $(P G M)$. The buffer systems found to be most suitable for resolving the above loci are listed in Table 1. Staining techniques for these enzyme systems were adopted from Hebert \& Beaton (1989). Electromorphs were labelled alphabetically with 'A' as the fastest running electromorph.

\section{Genetic analysis}

The fixation index, $F_{\mathrm{ST}}$ is a measure of genetic differentiation among populations and can range between 0 (no genetic differentiation) and 1 (complete differentiation) (Wright, 1951). It has several equivalent interpretations. $F_{\mathrm{ST}}$ can be expressed as the absence of heterozygotes in subpopulations relative to what is expected in the total population (i.e. $F_{\mathrm{ST}}=\left(H_{\mathrm{T}}-H_{\mathrm{S}}\right) / H_{\mathrm{T}}$, where $H_{\mathrm{S}}$ is the average heterozygosity of subpopulations and $H_{\mathrm{T}}$ is the predicted total heterozygosity). $F_{\mathrm{ST}}$ also represents the standardized variance in allele frequencies among local populations (Weir, 1990). While these formulations of $F_{\mathrm{ST}}$ are for one locus and one allele, similar statistics can be estimated for two alleles at one locus (Wright, 1951) and for more alleles at many loci (as $G_{\mathrm{ST}}$; Nei, 1973, 1977; Birky et al., 1989). An alternative to $F_{\mathrm{ST}}$ is the statistic of coancestry, $\theta$, which represents the correlation of genes of different individuals in the same populations (Weir \& Cockerham, 1984; Weir, 1990).

For neutral alleles, $F_{\mathrm{ST}}, G_{\mathrm{ST}}$ or $\theta$, can be used to estimate the number of migrants exchanged by populations per generation (gene flow) $\left(F_{\mathrm{ST}}=1 /\left(4 N_{\mathrm{e}} m+1\right)\right.$, where $N_{\mathrm{e}}$ is the effective local population size and $m$ is the average rate of immigration or the proportion of the population that migrate each generation (Wright, 1943)). By estimating $N_{\mathrm{e}} m$ we can compare the magnitude of gene flow without the need for exact estimates of the average effective population size, $N_{\mathrm{e}}$.

Wright's formula assumes an 'island model' in which every local population is equally likely to exchange migrants with any other. However, the formula also

Table 1 Presumptive loci scored for Coleomegilla maculata

\begin{tabular}{|c|c|c|c|}
\hline Enzyme & E.C. & Locus $\dagger$ & Buffer $\neq$ \\
\hline Fumarate hydratase & 4.2.1.2 & FUM & Tris-EDTA-Borate $0.13 \mathrm{~m}, p \mathrm{H} 8.9$ \\
\hline Isocitrate dehydrogenase & 1.1.1.42 & $\begin{array}{l}I D H-f \\
I D H-s\end{array}$ & $\begin{array}{l}\text { Citrate Phosphate } 0.01 \mathrm{M}, p \mathrm{H} 6.4 \\
\text { Citrate Phosphate } 0.01 \mathrm{M}, p \mathrm{H} 6.4\end{array}$ \\
\hline Malate dehydrogenase & 1.1.1.37 & $\begin{array}{l}M D H-f \\
M D H-s\end{array}$ & $\begin{array}{l}\text { Tris-Maleate-EDTA- } \mathrm{MgCl}_{2} 0.05 \mathrm{M}, p \mathrm{H} 7.8 \\
\text { Tris-Citrate } 0.1 \mathrm{M}, \mathrm{pH} 8.2\end{array}$ \\
\hline Peptidase & $3.4 .11-13$ & PEP & Tris-Glycine $0.025 \mathrm{M}, p \mathrm{H} 8.5$ \\
\hline 6-Phosphogluconate dehydrogenase & 1.1.1.44 & $6 P G D H$ & Tris-Maleate-EDTA- $\mathrm{MgCl}_{2} 0.05 \mathrm{M}, p \mathrm{H} 7.8$ \\
\hline Phosphoglucose isomerase & 5.3 .1 .9 & $P G I$ & Citrate Phosphate $0.01 \mathrm{~m}, p \mathrm{H} 6.4$ \\
\hline Phosphoglucomutase & 2.7.5.1 & $P G M$ & $\begin{array}{l}\text { Tris-Glycine } 0.025 \mathrm{M}, p \mathrm{H} 8.5 \text { and } \\
\text { Tris-Maleate-EDTA- } \mathrm{MgCl}_{2} 0.05 \mathrm{M}, p \mathrm{H} 7.8\end{array}$ \\
\hline
\end{tabular}

$\dagger \mathrm{f}=$ fast and $\mathrm{s}=$ slow electromorphs.

$\ddagger$ Hebert \& Beaton (1989). 
approximates gene flow for two-dimensional steppingstone models (Crow \& Aoki, 1984; Crow, 1986; Slatkin, 1987). Indirect methods to estimate gene flow rely on several rarely evaluated assumptions. Four major assumptions must be made (Daly, 1989). (i) Gene flow is random with respect to the genotypes studied. (ii) The rate of gene flow for the studied alleles exceeds the rate of change of allele frequencies due to selection. (iii) The rate of gene flow exceeds a minimum level to offset the effects of genetic drift. (iv) The populations are at genetic equilibrium, such that a balance is achieved between loss of alleles by drift and the gain of alleles from migration. These assumptions are considered in turn below.

The first two assumptions are likely to be met for allozymes that are considered to be either neutral or under weak selection (Kimura, 1983). Also, if many loci give similar results, it would be difficult to argue that all are responding to the same selective pressures (Slatkin, 1987). The last two assumptions are more difficult. For the third assumption, Wright (1931) showed that any gene flow among populations will prevent complete fixation and that genetic drift will only lead to substantial genetic differentiation if gene flow does not exceed a certain minimum level. This condition can be expressed as $m \gg 1 /\left(4 N_{\mathrm{e}}\right)$ or $N_{\mathrm{e}} m \gg 1 / 4$ (Wright, 1931). Free-living, mobile organisms usually have much higher levels of gene flow. The fourth assumption states that the populations are in genetic equilibrium, such that loss of alleles by genetic drift in any population is balanced by a gain in alleles through migration. At equilibrium this balance will hold over a range of population sizes (Slatkin, 1987). Because C. maculata is native to North America, we argue that there has been sufficient time for the effects of migration to balance the effects of genetic drift.

Slatkin \& Barton (1989) suggested that estimation of gene flow based on $F_{\mathrm{ST}}$ methods (including $G_{\mathrm{ST}}$ and $\theta$ ) is preferable to other methods that use allele frequency data (such as, the private alleles and maximum likelihood methods; Slatkin \& Barton, 1989). The use of rare or private alleles (Slatkin, 1985b) is more sensitive to coding errors than methods based on $F_{\mathrm{ST}}$ and maximum likelihood methods appear to overestimate gene flow unless a large number of populations (perhaps as many as 40) is sampled (Slatkin \& Barton, 1989). For high rates of gene flow, $G_{\mathrm{ST}}$ may be a better estimate of gene flow than $\theta$, which appears to overestimate $N_{\mathrm{e}} m$ (Slatkin \& Barton, 1989). When the number of sampled populations is small, the relationship between $G_{\mathrm{ST}}$ and $N_{\mathrm{e}} m$ may be better estimated by $G_{\mathrm{ST}}=1 /\left(1+4 N_{\mathrm{e}} m(n / n-1)^{2}\right)($ Takahata, 1983; Takahata \& Nei, 1984; Chakraborty \& Leimar, 1987). In this study, therefore, we present estimates of $\theta$ and corrected $G_{\mathrm{ST}}$.
We used BIosys-1 (FORTRAN 77 version, Swofford $\&$ Selander, 1981) to analyse gene frequency data. For each locus, as well as over all loci, we estimated $G_{\mathrm{ST}}$ and $\theta$ as well as $F_{\mathrm{IS}}$, which measures deviation from random mating within subpopulations. We scored 6-11 alleles per locus and could not completely resolve one allele ( $P E P$, allele G; Appendix A).

To test the assumption of Wright's (1951) island model (i.e. that a migrant from a population is equally likely to move to any other population), we correlated a measure of genetic distance between pairs of populations (Roger's Modified Distance; Wright, 1978) against the geographical distance between these populations. We used a resampling procedure (Mantel's test; Mantel, 1967; Crowley, 1992) to correct for lack of independency between data points.

Finally, we tested whether the $\theta$ estimate (unbiased regardless of sample size: Chakraborty \& Leimar, 1987) for C. maculata is lower than that for L. decemlineata (G. K. Roderick et al. and M. L. Azeredo-Espin et al., both unpublished data). Both sets of estimates were obtained over the same geographical area in Maryland. We used nine loci for C. maculata and six for $L$. decemlineata. Because sampling distributions of gene diversity components are not known, we used the Mann-Whitney $U$-test (SAS Institute, 1985) to compare the two estimates of $\theta$.

\section{Results}

Electromorph frequency data are presented in Appendix A. Data indicate that $C$. maculata has an extremely high number of alleles per locus $(9.44 \pm 0.73)$. Similarly, Steiner \& Grasela (1993) found twice as many alleles per locus in $C$. maculata than in other beetle species. In our study, allozyme frequencies did not deviate significantly from Hardy-Weinberg expectations $\left(\chi^{2}\right.$ goodness-of-fit test with a Sidak adjusted $P$ value; Sokal \& Rohlf, 1981). Thus, within the six studied populations, there is no evidence of significant deviations from random mating for any of the loci (also suggested by the relatively low $F_{\text {IS }}$ value; Table 3 ).

Contingency chi-square analysis revealed that there were no significant differences in allele frequencies at each locus across populations $\left(\chi^{2}=80.67\right.$, d.f. $=75$, $0.1<P<0.5)$. Mean rate of heterozygosity $(\mathrm{H})$ over all six populations was $0.250 \pm 0.021$ (range $0.212-0.273$ ). This level of heterozygosity is one of the highest found in beetles (Steiner \& Grasela, 1993). In our study, no longitudinal or latitudinal cline effects were found in allele frequency data. Recently, a cline in heterozygosity in C. maculata was found to be associated with latitude and host crop (Steiner \& Grasela, 1993). We did not find such cline effects in our study, probably because all beetles were collected near maize 
fields and the latitudinal distance was about 12 times smaller than in Steiner \& Grasela's study.

Roger's genetic distances between beetle populations averaged $0.059 \pm 0.009$ (Table 2). The lack of a relationship between genetic distance and geographic distance (Mantel statistic $=-0.256,95$ per cent confidence limits $=-0.51$ and 0.50$\rangle$ provides no evidence with which to reject the island model.

The low estimates of $\theta$ and $G_{\mathrm{ST}}$ (Table 3 ) indicate little genetic differentiation among populations. The negative $\theta$ 's indicate values close to zero because $\theta$ is not defined for negative values (Weir, 1990). The $\theta$ and $G_{\mathrm{ST}}$-based estimated numbers of beetles exchanged between populations per generation $\left(N_{\mathrm{e}} m\right)$ were 166.4 and 15.6 , respectively.

In the same geographical region of the present study, $\theta$ for the Colorado potato beetle was $0.0157( \pm 0.00 \dot{4} 4$ S.E.), suggesting a level of migration $\left(N_{\mathrm{e}} m\right)$ of 15.67 . This value of $\theta$ is significantly smaller than the value

Table 2 Genetic distance between pairs of six populations of Coleomegilla maculata $\dagger$

\begin{tabular}{lcccccc}
\hline Populations & KEED & R-28 & DAM & R-108 & BELT & R-424 \\
\hline KEED & - & & & & & \\
R-28 & 0.058 & - & & & & \\
DAM & 0.077 & 0.071 & - & & & \\
R-108 & 0.067 & 0.056 & 0.058 & - & & \\
BELT & 0.060 & 0.058 & 0.065 & 0.051 & - & \\
R-424 & 0.052 & 0.044 & 0.056 & 0.048 & 0.060 & - \\
\hline
\end{tabular}

†Modified Roger's genetic distance (Wright, 1978).

Table 3 Statistics summary from six populations of Coleomegilla maculata

\begin{tabular}{lrrr}
\hline Locus & \multicolumn{1}{c}{$F_{\mathrm{IS}}$} & \multicolumn{1}{c}{$\theta \dagger$} & $G_{\mathrm{ST}}{ }^{\dagger}$ \\
\hline FUM & -0.031 & -0.0055 & 0.005 \\
$I D H-f$ & 0.119 & 0.0042 & 0.015 \\
$I D H-s$ & 0.038 & 0.0006 & 0.011 \\
$M D H-f$ & 0.098 & 0.0030 & 0.013 \\
$M D H-s$ & -0.023 & -0.0021 & 0.008 \\
$P E P$ & 0.056 & -0.0003 & 0.010 \\
$6 P G D H$ & 0.011 & -0.0037 & 0.007 \\
$P G l$ & 0.031 & 0.0047 & 0.014 \\
$P G M$ & 0.007 & 0.0010 & 0.011 \\
Mean & 0.033 & $0.0015 \S$ & 0.011 \\
S.E. & 0.017 & $0.0006 \S$ & 0.001 \\
\hline
\end{tabular}

$\dagger$ Weir \& Cockerham (1984); Weir (1990). $\ddagger \mathrm{Nei}(1977)$.

$\S$ Corrected values (negative $\theta$ s were entered as 0 s). Uncorrected mean and S.E. are 0.0002 and 0.0012 , respectively). estimated for $C$. maculata (Mann-Whitney $U$-test, $P=0.016)$.

\section{Discussion}

Little genetic differentiation exists among $C$. maculata populations in Maryland. Given the long history of these populations, these data suggest relatively high rates of gene flow among populations. Through simulations, Slatkin \& Barton (1989) demonstrated that for high levels of gene flow, $G_{\mathrm{ST}}$ underestimates $N_{\mathrm{e}} m$, especially when a small number of populations is sampled (Chakraborty \& Leimar, 1987). The same pattern appears in our study, i.e. $G_{\mathrm{ST}}$-based $N_{\mathrm{e}} m$ is about seven times smaller than the $\theta$-based estimate.

The mean value for $\theta$ in this study $(0.0015)$ is an order of magnitude smaller than the value estimated in another predatory coccinellid beetle, Coccinella septempunctata, in North America $(\theta=0.0148$; Krafsur et al., 1992). Krafsur et al. (1992) suggested that the low $\theta$ value for $C$. septempunctata is the result of its recent introduction into North America (Angalet et al., 1979). C. maculata, however, is native to North America and its populations are likely to have reached genetic equilibrium. Furthermore, genetic differentiation among native populations of $C$. septempunctata (i.e. in Eurasia) was even lower (0.003; Krafsur et al., 1992) and more similar to our estimates for $C$. maculata. Recently, a low level of genetic differentiation $\left(F_{\mathrm{ST}}=0.14\right)$ was also reported in $C$. maculata in the midwest region of the U.S.A. (Steiner \& Grasela, 1993).

Low levels of genetic differentiation may result from aggregative behaviour exhibited by many coccinellid beetles at overwintering sites (Hagen, 1962; Hodek, 1973). However, unlike other coccinellids (e.g. Coccinella septempunctata, Hippodemia convergens), $C$. maculata does not exhibit such long distance seasonal migratory behaviour. Instead, adult $C$. maculata aggregate at the base of prominent objects near open areas, such as fields (Hagen, 1962). Alternatively, low $F_{\mathrm{ST}}$ 's and the associated high $N_{\mathrm{e}} m$ values in coccinellid species may reflect generally high mobility of these efficient predators.

However, predator-prey interactions will be influenced not so much by the absolute movement rate of predators but rather by the relative mobility of predators and their prey. C. maculata is a generalist predator that consumes primarily aphids, insect eggs and immatures (Groden et al., 1990; Hazzard et al., 1991). It was therefore of interest to compare the genetic differentiation among populations of $C$. maculata in our study with genetic differentiation among populations of its prey. In Maryland, and elsewhere in the eastern U.S.A., C. maculata is an important predator of 
Colorado potato beetle eggs and young larvae (Groden et al., 1990; Hazzard \& Ferro, 1991; Hazzard et al., 1991). Over the same geographical area, estimates of genetic differentiation for the Colorado potato beetle were significantly greater than for $C$. maculata and therefore the estimated level of migration was significantly lower than that for C. maculata.

Greater levels of population differentiation, relative to $C$. maculata, were also evidenced in other prey species. For several North American lepidopteran pests fed on by $C$. maculata, $F_{\mathrm{ST}}$ ranged from 0.021 to 0.084 (Pashley et al., 1985) and for surface-dwelling coleopteran prey (excluding predatory and cavedwelling species) $F_{\mathrm{ST}}$ values ranged from 0.011 to 0.154 (McCauley \& Eanes, 1987; Hsiao, 1989). By contrast, small genetic differentiation of C. maculata, suggests that its movement may be one or even two orders of magnitude greater than that of its prey. This difference in mobilities may help to explain the remarkable efficiency of $C$. maculata, even in the face of a yearly habitat destruction as found in annual cropping systems.

Differential mobility of predators and their prey is also likely to be important in the evolution of pesticide resistance. Often, pest species are more resistant to pesticides than natural enemies (Croft \& Brown, 1975; Tabashnik, 1986). Two hypotheses have been advanced to explain this phenomenon; preadaptation (Gordon, 1961) and food limitation (Huffaker, 1971; Georghiou, 1972). Our results suggest yet another mechanism: the higher mobility of natural enemies relative to their prey may slow the evolution of pesticide resistance: (1) because natural enemies may move more readily out of treated areas (in response to prey scarcity) and thus be less exposed to pesticide selection pressure and/or (2) because more susceptible individuals may immigrate into treated fields to dilute the selective effect of pesticides. These effects, however, may be confounded by a greater exposure of the more mobile natural enemies to pesticide residues in treated areas.

Much like herbivores, individuals of $C$. maculata show resistance to insecticides in heavily-treated areas (Head et al., 1977; Graves et al., 1978). Models have demonstrated that high levels of gene flow (more than 10 per cent) between treated and untreated fields can retard the evolution of resistance in treated fields, on the one hand, and increase the frequency of resistance alleles in untreated fields, on the other (Caprio \& Tabashnik, 1992b). Assuming that population density of $C$. maculata in maize is similar across our sampling region, population sizes in fields adjacent to the sampled aggregations (based on densities in our western collecting site; Coll \& Bottrell, 1991) are esti- mated at approximately 100,000 adults. Because the effective population size may be smaller by as much as 90 per cent (Wright, 1978), an upper limit of the average migration rate, $m$, is $0.02 \quad\left(N_{\mathrm{e}} m=166.4\right.$; $\left.N_{\mathrm{e}}=10,000\right)$. Gene flow at this level is too low to retard significantly the development of resistance in $C$. maculata by high immigration of susceptible beetles from untreated fields and yet is too high to slow the spread of initially rare, resistant alleles (Caprio \& Tabashnik, 1992a,b).

The mobility of predators and parasites in both natural and managed systems is clearly important in determining the stability of predator-prey interactions and in insect pest control. Yet, few previous studies have examined the population structures of both predator and prey in the same system (Taylor, 1991). Such studies are likely to be rewarding not only for what they will reveal about the organisms themselves but also for what they will contribute to our understanding of population dynamics and community organization.

\section{Acknowledgements}

We thank C. Smith for assistance, C. Mitter and M. M. Yang for advice and R. Gillespie, A. Hilbeck, M. Johnson and an anonymous reviewer for helpful comments on drafts of the manuscript. This work was funded by grants from the USDA (to G.K.R.), the Maryland Agricultural Experiment Station Competitive Grants Program (to G.K.R. and M.C.), the General Research Board of the University of Maryland (to G.K.R.), and NIH Biomedical Research Funds (to G.K.R.). The Department of Entomology, University of Maryland and the Hawaiian Evolutionary Biology Program, University of Hawaii, provided additional support. This is scientific article A6414, contribution 8607, of the Maryland Agricultural Experiment Station.

\section{References}

ANGAlet, G. W., Tropp, J. M. AND EgGERT, A. N. 1979. Coccinella septempunctata in the United States: recolonization and notes on its ecology. Environ. Entomol., 8, 896-901.

ATALlAH, Y. H. AND NEWSOM, L. D. 1966. Ecological and nutritional studies on Coleomegilla maculata De Geer (Coleoptera: Coccinellidae). I. The development of an artificial diet and a laboratory rearing technique. J. Econ. Entomol., 59, 1173-1180.

BIRKY, C. W., FUERST, P. AND MARUYAMA, T. 1989. Organelle gene diversity under migration, mutation and drift: equilibrium expectations, approach to equilibrium, effects of heteroplasmic cells and comparison of nuclear genes. Genetics, 121, 613-627. 
BUTLIN, R. K. 1990. Divergence in emergence time of host races due to differential gene flow. Heredity, 65, 47-50.

CAPRIO, M. A. AND TABASHNIK, B. E. 1992a. Allozymes used to estimate gene flow among populations of diamondback moth (Lepidoptera: Plutellidae) in Hawaii. Environ. Entomol., 21, 808-816.

CAPRIO, M. A. AND TABASHNIK, B. E. 1992b. Gene flow accelerates local adaptation among finite populations: simulating the evolution of insecticide resistance. J. Econ. Entomol., 85, 611-620.

CHAKRABORTY, R. AND LEIMAR, o. 1987. Genetic variation within a subdivided population. In: Ryman, N. and Utter, F. (eds) Population Genetics and Fisheries Management. pp. 80-120. University of Washington Press, Seattle, Washington.

COLL, M. 1991. Effects of vegetation texture on the Mexican bean beetle and its parasitoid, Pediobius foveolatus. Ph.D. Dissertation. University of Maryland.

COLL, M. AND BOTTRELL, D. G. 1991. Microhabitat and resource selection of the European corn borer (Lepidoptera: Pyralidae) and its natural enemies in Maryland field corn. Environ. Entomol, 20, 526-533.

COMINS, H. N. 1977. The development of insecticide resistance in the presence of migration. J. Theor. Biol., 64, 177-197.

COSPER, R. D., GAYLOR, M. J. AND WILLIAMS, J. C. 1983. Intraplant distribution of three insect predators on cotton and seasonal effects of their distribution on vacuum sampler efficiency. Environ. Entomol., 12, 1568-1571.

CROFT, B. A. AND BRown, A. W. A. 1975. Response of arthropod natural enemies to insecticides. Ann. Rev. Entomol., 20, 285-355.

CRow, J. F. 1986. Basic Concepts in Population, Quantitative and Evolutionary Genetics. W. H. Freeman, New York.

CROW, J. F. AND AOKI, K. 1984. Group selection for a polygenic behavioral trait: estimating the degree of population subdivision. Proc. Natl. Acad. Sci. U.S.A., 81, 6073-6077.

CROWLEY, P. H. 1992. Resampling methods for computationintensive data analysis in ecology and evolution. Ann. Rev. Ecol. Syst., 23, 405-447.

DALY, J. C. 1989. The use of electrophoretic data in a study of gene flow in the pest species Heliothis armigera (Hübner) and $H$. punctigera Wallengren (Lepidoptera: Noctuidae). In: Loxdale, H. D. and Den Hollander, J. (eds) Electrophoretic Studies on Agricultural Pests, pp. 115-141. Clarendon Press, Oxford.

EHRLICH, P. R. AND RAVEN, P. H. 1969. Differentiation of populations. Science, 165, 1228-1232.

ELSEY, K. D. 1974. Influence of plant host on searching speed of two predators. Entomophaga, 19, 197.

ENDLER, J. A. 1979. Gene flow and life history patterns. Genetics, 93, 263-284.

EWERT, M. A. AND CHIANG, H. C. 1966. Dispersal of three species of coccinellids in corn fields. Can. Ent., 98, 999-1003.

GEORGHIOU, G. P. 1972. The evolution of resistance to pesticides. Ann. Rev. Ecol. Syst., 3, 133-168.

GEORGHIOU, G. P. AND TAYLOR, c. E. 1977. Genetic and biological influences in the evolution of insecticide resistance. J. Econ. Entomol., 7, 319-323.

GORDON, H. T. 1961. Nutritional factors in insect resistance to chemicals. Ann. Rev. Entomol., 6, 27-54.
GRAVES, J. B., MOHAMAD, R. B. AND ClOWER, D. F. 1978. Beneficial insects [Coleomegilla maculata, Caocoria punatipes, Orius insidiscus] also developing 'resistance' [Biological control with insect predators and parasites]. La-Agric., 22, 11-12.

GRODEN, E., DRUMMOND, F. A., CASAGRANDE, R. A. AND HAYNES, D. L. 1990. Coleomegilla maculata (Coleoptera: Coccinellidae): its predation upon the Colorado potato beetle (Coleoptera: Chrysomelidae) and its incidence in potatoes and surrounding crops. J. Econ. Entomol., 83, 1306-1315.

HAGEN, K. S. 1962. Biology and ecology of predacious coccinellidae. Ann. Rev. Entomol., 7, 289-326.

HASSEl, M. P. 1978. The Dynamics of Arthropod Predator-Prey Systems. Princeton University Press, Princeton, New Jersey.

HASSELL, M. P. AND MAY, R. M. 1988. Spatial heterogeneity and the dynamics of parasitoid-host systems. Ann. Zoo. Fennici, 25, 55-61.

HAZZARD, R. V. AND FERRO, D. N. 1991. Feeding responses of adult Coleomegilla maculata (Coleoptera: Coccinellidae) to eggs of Colorado potato beetle (Coleoptera: Chrysomelidae) and green peach aphids (Homoptera: Aphididae). Environ. Entomol., 20, 644-651.

HAZZARD, R. V., FERRO, D. N., VAN DRIESHE, R. G. AND TUTTLE, A. F. 1991. Mortality of eggs of Colorado potato beetle (Coleoptera: Chrysomelidae) from predation by Coleomegilla maculata (Coleoptera: Coccinellidae). Environ. Entomol., 20, 841-848.

HEAD, R., NEEL, W. W., SARTOR, C. F. AND CHAMBERS, H. 1977. Methyl parathion and carbaryl resistance in Chrysomela scripta and Coleomegilla maculata. Bull. Env. Contam. Tox., 17, 163-164.

HEBERT, P. D. N. AND BEATON, M. J. 1989. Methodologies for Allozyme Analysis Using Cellulose Acetate Electrophoresis. Helena Laboratories, Beaumont Texas.

HODEK, I. 1973. Biology of Coccinellidae. Academia, Prague. HSIAO, T. H. 1989. Estimation of genetic variability amongst Coleoptera. In: Loxdale, H. D. and den Hollander, J. (eds) Electrophoretic Studies on Agricultural Pests, pp. 143-180. Clarendon Press, Oxford.

HUFFAKER, C. B. 1971. The ecology of pesticide interference with insect populations. In: Swift, J. E. (ed.) Agricultural Chemicals - Harmony or Discord for Food, People and the Environment, pp. 92-107. University of California, Berkeley, California.

kimura, m. 1983. The Neutral Theory of Evolution. Cambridge University Press, Cambridge.

KRAFSUR, E. S., OBRYCKI, J. J. AND FLANDERS, R. v. 1992. Gene flow in populations of the seven-spotted lady beetle, Coccinella septempunctata. J. Hered., 83, 440-444.

LOXDAlE, H. D. AND DEN Hollander, J. (eds) 1989. Electrophoretic Studies on Agricultural Pests. Clarendon Press, Oxford.

MANTEL, N. 1967. The detection of disease clustering and a generalized regression approach. Cancer Res., 27, 209-220.

MARCK, T. P. AND SMILOWITZ, z. 1982. CMACSIM, a temperature-dependent predator-prey model simulating the impact of Coleomegilla maculata (De Geer) on green peach aphids on potato plants. Environ. Entomol., 11, 1193-1201. 
McCAULEY, D. E. 1991. Genetic consequences of local population extinction and recolonization. Trends Ecol. Evol., 6, 5-8.

McCAULEY, D. E. AND EANES, W. F. 1987. Hierarchical population structure analysis of the milkweed beetle, Tetraopes tetraophthalmus (Forster). Heredity, 58, 193-201.

MURDOCH, w. W., CHESSON, J. AND CHESSON, P. 1985. Biological control in theory and practice. Am. Nat., 125, 344-366.

NEI, M. 1973. Analysis of gene diversity in subdivided populations. Proc. Natl. Acad. Sci. U.S.A., 70, 3321-3323.

NEI, M. 1977. F-statistics and analysis of gene diversity in subdivided populations. Ann. Hum. Genet., 41, 225-233.

OBRYCKI, J. J. AND TAUBER, M. J. 1978. Thermal requirements for development of Coleomegilla maculata (Coleoptera: Coccinellidae) and its parasite Perilitus coccinellae (Hymenoptera: Braconidae). Can. Ent., 110, 407-412.

PASHLEY, D. P., JOHNSON, S. J. AND SPARKS, A. N. 1985. Genetic population structure of migratory moths: the fall armyworm (Lepidoptera: Noctuidae). Ann. Entomol. Soc. Am., 78, 756-762.

RICHARDSON, B. J., BAVERSTOCK, P. R. AND ADAMS, M. 1986. Allozyme Electrophoresis. Academic Press, New York.

RICHARDSON, J. V. AND DELOACH, C. J. 1973. Seasonal abundance of Perilitus coccinellae and its coccinellid hosts and degree of parasitism in Central Missouri. Environ. Entomol., 2, $138-141$.

RODERICK, G. K. 1992. Post-colonization evolution of natural enemies. In: Kauffman, W. C. and Nechols, J. R. (eds) Selection Criteria and Ecological Consequences of Importing Natural Enemies. Thomas Say Publ. of Entomological Society of America, 1, 71-86.

RODERICK, G. K. 1993. Genetics of host plant adaptation in planthoppers (Homoptera: Delphacidae). In: Denno, R. F. and Perfect, J. (eds) Planthoppers: Their Ecology, Genetics and Management, pp. 257-281. Chapman and Hall, New York.

RODERICK, G. K. AND CALDWELL, R. L. 1992. An entomological perspective on animal dispersal. In: Stenseth, N. C. and Lidicker, W. Z. (eds) Animal Migration, pp. 274-290. Chapman and Hall, New York.

ROSENHEIM, J. A. AND HOY, M. A. 1986. Intraspecific variation in levels of pesticide resistance in field populations of a parasitoid, Aphytis melinus (Hymenoptera: Aphelinidae): the role of past selection pressures. J. Econ. Entomol, 79, 1161-1173.

ROSENHEIM, J. A. AND TABASHNIK, B. E. 1991. Influence of generation time on the rate of response to selection. Am. Nat., 137, 527-541.

SAS INSTTTUTE 1985. SAS User's Guide: Statistics, version 5. Cary, North Carolina.

SLATKIN, M. 1985a. Gene flow in natural populations. Ann. Rev. Ecol. Syst., 16, 393-430.

SLATKIN, M. 1985b. Rare alleles as indicators of gene flow. Evolution, 39, 53-65.

SLATKIN, M. 1987. Gene flow and geographic structure of natural populations. Science, 236, 787-792.

SLATKIN, M. AND BARTON, N. H. 1989. A comparison of three indirect methods for estimating average levels of gene flow. Evolution, 43, 1349-1368.

SMITH, B. C. 1960 . A technique for rearing coccinellid beetles on dry foods and influence of various pollens on the development of Coleomegilla maculata Lengi Timb. (Coleoptera: Coccinellidae). Can. J. Zool., 38, 1047-1049.

SOKAL, R. R. AND ROHLF, F. J. 1981. Biometry, 2nd edn. W.H. Freeman and Co., New York.

STEINER, W. W. M. AND GRASELA, J. J. 1993. Population genetics and gene variation in the predator, Coleomegilla maculata (De Geer) (Coleoptera: Coccinellidae). Ann. Entomol. Soc. Am., 86, 309-321.

STRONG, D. R. 1988. Parasitoid theory: from aggregation to dispersal. Trends Ecol. Evol., 3, 277-280.

SWOFFORD, D. L. AND SELANDER, R. B. 1981. Biosys-1: a Fortran program for the comprehensive analysis of electrophoretic data in population genetics and systematics. J. Hered., 72, 281-283.

TABASHNIK, B. E. 1986. Evolution of pesticide resistance in predator/prey systems. Bull. Entomol. Soc. Am., 32, 156-161.

TABASHNIK, B. E. AND CROFT, B. A. 1982. Managing pesticide resistance in crop-arthropod complexes: interactions between biological and operation factors. Environ. Entomol., 11, 1137-1144.

TAKAHATA, N. 1983. Gene identity and genetic differentiation of populations in the finite island model. Genetics, 104, 497-512.

TAKAHATA, N. AND NEI, M. $1984 . F_{\mathrm{ST}}$ and $G_{\mathrm{ST}}$ statistics in the finite island model. Genetics, 107, 501-504.

TAYLOR, A. D. 1991. Studying metapopulation effects in predator prey systems. Biol. J. Linn. Soc., 42, 305-323.

TAYLOR, C. E. AND GEORGHIOU, G. P. 1979. Suppression of insecticide resistance by alteration of gene domination and migration. J. Econ. Entomol., 72, 105-109.

WARREN, L. O. AND TADIC, M. 1967. Biological observations on Coleomegilla maculata and its role as a predator of the fall webworm. J. Econ. Entomol., 60, 1492-1496.

WEIR, B. s. 1990. Genetic Data Analysis. Sinauer Associates, Sunderland, MA.

WEIR, B. S. AND COCKERHAM, C. C. 1984 . Estimating $F$-statistics for the analysis of population structure. Evolution, 38, $1358-1370$.

WRIGHT, s. 1931. Evolution in Mendelian populations. Genetics, 16, 97-159.

WRIGHT, s. 1943. Isolation by distance. Genetics, 16, 114-138.

WRight, s. 1951. The genetical structure of populations. Ann. Eugen., 15, 323-354.

WRIGHT, s. 1978. Evolution and the Genetics of Populations, vol. 4. Variability Within and Among Natural Populations. University of Chicago Press, Chicago.

WRIGHT, E. J. AND LAING, J. E. 1980. Numerical response of coccinellids to aphids in corn in southern Ontario. Can. Ent., 112, 977-988. 


\section{Appendix A}

Electromorph frequencies and sample size $(N)$ for six populations of Coleomegilla maculata. See Table 1 and Fig. 1 for abbreviations of loci and populations, respectively

Population

Locus Allele KEED R-28 DAM R-108 BELT R-424

\begin{tabular}{cccccccc}
\hline FUM & (N) & 45 & 45 & 46 & 46 & 35 & 45 \\
$\mathrm{~A}$ & 0.000 & 0.000 & 0.011 & 0.000 & 0.000 & 0.000 \\
$\mathrm{~B}$ & 0.000 & 0.011 & 0.000 & 0.000 & 0.000 & 0.000 \\
$\mathrm{C}$ & 0.000 & 0.011 & 0.000 & 0.000 & 0.000 & 0.000 \\
$\mathrm{D}$ & 0.000 & 0.000 & 0.000 & 0.011 & 0.000 & 0.000 \\
$\mathrm{E}$ & 0.011 & 0.011 & 0.000 & 0.011 & 0.000 & 0.011 \\
$\mathrm{~F}$ & 0.956 & 0.944 & 0.967 & 0.946 & 0.971 & 0.944 \\
$\mathrm{G}$ & 0.011 & 0.000 & 0.011 & 0.011 & 0.000 & 0.000 \\
$\mathrm{H}$ & 0.000 & 0.000 & 0.000 & 0.000 & 0.014 & 0.011 \\
$\mathrm{I}$ & 0.000 & 0.000 & 0.000 & 0.011 & 0.000 & 0.011 \\
$\mathrm{~J}$ & 0.011 & 0.000 & 0.000 & 0.000 & 0.000 & 0.000 \\
$\mathrm{~K}$ & 0.011 & 0.022 & 0.000 & 0.000 & 0.014 & 0.011 \\
$\mathrm{~L}$ & 0.000 & 0.000 & 0.011 & 0.011 & 0.000 & 0.000 \\
$\mathrm{M}$ & 0.000 & 0.000 & 0.000 & 0.000 & 0.000 & 0.011
\end{tabular}

$\begin{array}{llllllll}I D H-f & (\mathrm{~N}) & 45 & 44 & 46 & 46 & 35 & 45\end{array}$

$\begin{array}{lllllll}\text { A } & 0.000 & 0.000 & 0.000 & 0.000 & 0.014 & 0.000\end{array}$

$\begin{array}{lllllll}\text { B } & 0.011 & 0.000 & 0.000 & 0.000 & 0.000 & 0.000\end{array}$

$\begin{array}{lllllll}\text { C } & 0.011 & 0.000 & 0.011 & 0.000 & 0.000 & 0.000\end{array}$

$\begin{array}{lllllll}\mathrm{D} & 0.000 & 0.023 & 0.033 & 0.000 & 0.014 & 0.000\end{array}$

$\begin{array}{llllllll}\text { E } & 0.000 & 0.000 & 0.000 & 0.000 & 0.014 & 0.000\end{array}$

$\begin{array}{llllllll}\text { F } & 0.967 & 0.909 & 0.946 & 0.957 & 0.886 & 0.978\end{array}$

$\begin{array}{lllllll}\text { G } & 0.011 & 0.034 & 0.011 & 0.043 & 0.029 & 0.022\end{array}$

$\begin{array}{lllllll}\mathrm{H} & 0.000 & 0.011 & 0.000 & 0.000 & 0.000 & 0.000\end{array}$

$\begin{array}{lllllll}\text { I } & 0.000 & 0.000 & 0.000 & 0.000 & 0.014 & 0.000\end{array}$

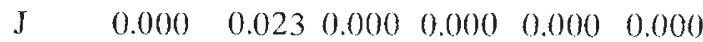

$\begin{array}{lllllll}\mathrm{K} & 0.000 & 0.000 & 0.000 & 0.000 & 0.029 & 0.000\end{array}$

$\begin{array}{llllllll}I D H-s & (\mathrm{~N}) & 45 & 43 & 46 & 46 & 35 & 46\end{array}$

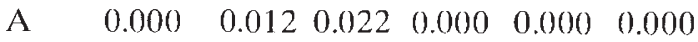

$\begin{array}{lllllll}\text { B } & 0.000 & 0.000 & 0.000 & 0.000 & 0.000 & 0.022\end{array}$

$\begin{array}{lllllll}\text { C } & 0.011 & 0.012 & 0.000 & 0.000 & 0.000 & 0.000\end{array}$

$\begin{array}{llllllll}\text { D } & 0.000 & 0.012 & 0.011 & 0.011 & 0.014 & 0.033\end{array}$

$\begin{array}{lllllll}\text { E } & 0.956 & 0.953 & 0.935 & 0.967 & 0.986 & 0.913\end{array}$

$\begin{array}{lllllll}\mathrm{F} & 0.000 & 0.012 & 0.000 & 0.000 & 0.000 & 0.000\end{array}$

$\begin{array}{lllllll}\mathrm{G} & 0.022 & 0.000 & 0.022 & 0.000 & 0.000 & 0.000\end{array}$

$\begin{array}{lllllll}\mathrm{H} & 0.000 & 0.000 & 0.000 & 0.011 & 0.000 & 0.011\end{array}$

$\begin{array}{lllllll}\mathrm{J} & 0.011 & 0.000 & 0.000 & 0.011 & 0.000 & 0.022\end{array}$

$\begin{array}{lllllll}\mathrm{J} & 0.000 & 0.000 & 0.011 & 0.000 & 0.000 & 0.000\end{array}$

$\begin{array}{lllllll}M D H-f(\mathrm{~N}) & 45 & 45 & 46 & 46 & 35 & 46\end{array}$

$\begin{array}{lllllll}\text { A } & 0.000 & 0.000 & 0.000 & 0.000 & 0.014 & 0.000\end{array}$

$\begin{array}{lllllll}\text { B } & \quad 0.000 & 0.000 & 0.000 & 0.011 & 0.014 & 0.000\end{array}$

$\begin{array}{lllllll}\text { C } & 0.000 & 0.000 & 0.000 & 0.011 & 0.014 & 0.000\end{array}$

$\begin{array}{lllllll}\text { D } & 0.978 & 1.000 & 0.978 & 0.935 & 0.957 & 0.978\end{array}$

$\begin{array}{lllllll}\text { E } & 0.000 & 0.000 & 0.000 & 0.022 & 0.000 & 0.022\end{array}$

$\begin{array}{lllllll}\mathrm{F} & 0.022 & 0.000 & 0.011 & 0.022 & 0.000 & 0.000\end{array}$

$\begin{array}{lllllll}\text { G } & 0.000 & 0.000 & 0.011 & 0.000 & 0.000 & 0.000\end{array}$

$\begin{array}{llllllll}M D H-s & (\mathrm{~N}) & 45 & 45 & 46 & 46 & 35 & 45\end{array}$

$\begin{array}{lllllll}\text { A } & 0.011 & 0.000 & 0.000 & 0.011 & 0.000 & 0.000\end{array}$

$\begin{array}{lllllll}\text { B } & 0.000 & 0.000 & 0.011 & 0.011 & 0.000 & 0.000\end{array}$
Population

Locus Allele KEED R-28 DAM R-108 BELT R-424

\begin{tabular}{ccccccccc}
\hline & & & & & & & \\
& $\mathrm{C}$ & 0.000 & 0.000 & 0.000 & 0.011 & 0.000 & 0.000 \\
$\mathrm{D}$ & 0.989 & 0.978 & 0.978 & 0.946 & 0.986 & 0.978 \\
$\mathrm{E}$ & 0.000 & 0.022 & 0.000 & 0.011 & 0.000 & 0.011 \\
$\mathrm{PEP}$ & $\mathrm{F}$ & 0.000 & 0.000 & 0.011 & 0.011 & 0.014 & 0.011 \\
& $\mathrm{~N})$ & 45 & 44 & 46 & 46 & 34 & 44 \\
$\mathrm{~A}$ & 0.000 & 0.000 & 0.011 & 0.033 & 0.000 & 0.023 \\
$\mathrm{~B}$ & 0.056 & 0.057 & 0.098 & 0.065 & 0.059 & 0.045 \\
$\mathrm{C}$ & 0.000 & 0.057 & 0.000 & 0.011 & 0.015 & 0.034 \\
$\mathrm{D}$ & 0.278 & 0.205 & 0.304 & 0.207 & 0.294 & 0.250 \\
$\mathrm{E}$ & 0.011 & 0.000 & 0.000 & 0.000 & 0.029 & 0.000 \\
$\mathrm{~F}$ & 0.533 & 0.625 & 0.467 & 0.587 & 0.559 & 0.580 \\
$\mathrm{G}$ & 0.100 & 0.023 & 0.109 & 0.087 & 0.044 & 0.068 \\
$\mathrm{H}$ & 0.011 & 0.011 & 0.000 & 0.000 & 0.000 & 0.000 \\
$\mathrm{I}$ & 0.011 & 0.000 & 0.011 & 0.000 & 0.000 & 0.000 \\
$\mathrm{~J}$ & 0.000 & 0.000 & 0.000 & 0.011 & 0.000 & 0.000 \\
$\mathrm{~K}$ & 0.000 & 0.023 & 0.000 & 0.000 & 0.000 & 0.000
\end{tabular}

$\begin{array}{lllllll}6 P G D H(\mathrm{~N}) & 43 & 44 & 46 & 46 & 35 & 45\end{array}$

$\begin{array}{lllllll}\text { A } & 0.000 & 0.023 & 0.011 & 0.000 & 0.000 & 0.000\end{array}$

$\begin{array}{llllllll}\text { B } & 0.000 & 0.000 & 0.011 & 0.011 & 0.000 & 0.000\end{array}$

$\begin{array}{lllllll}\text { C } & 0.000 & 0.000 & 0.000 & 0.022 & 0.000 & 0.011\end{array}$

$\begin{array}{lllllll}\mathrm{D} & 0.000 & 0.023 & 0.022 & 0.000 & 0.000 & 0.011\end{array}$

$\begin{array}{lllllll}\text { E } & 0.000 & 0.000 & 0.000 & 0.000 & 0.014 & 0.000\end{array}$

$\begin{array}{llllllll}\text { F } & 0.965 & 0.909 & 0.913 & 0.924 & 0.943 & 0.956\end{array}$

G $\quad \begin{array}{lllllll}0.023 & 0.011 & 0.011 & 0.011 & 0.014 & 0.000\end{array}$

$\begin{array}{lllllll}\mathrm{H} & 0.012 & 0.034 & 0.033 & 0.033 & 0.029 & 0.022\end{array}$

$\begin{array}{llllllll}P G I & (\mathrm{~N}) & 45 & 44 & 44 & 46 & 35 & 44\end{array}$

$\begin{array}{lllllll}\text { A } & 0.000 & 0.011 & 0.023 & 0.011 & 0.000 & 0.000\end{array}$

$\begin{array}{llllllll}\text { B } & 0.022 & 0.000 & 0.011 & 0.000 & 0.014 & 0.011\end{array}$

$\begin{array}{llllllll}\text { C } & 0.111 & 0.136 & 0.216 & 0.185 & 0.143 & 0.205\end{array}$

$\begin{array}{llllllll}\text { D } & 0.689 & 0.580 & 0.477 & 0.554 & 0.643 & 0.557\end{array}$

$\begin{array}{llllllll}\text { E } & 0.000 & 0.023 & 0.000 & 0.033 & 0.000 & 0.023\end{array}$

$\begin{array}{llllllll}\text { F } & 0.122 & 0.159 & 0.170 & 0.087 & 0.114 & 0.170\end{array}$

$\begin{array}{lllllll}\mathrm{G} & 0.022 & 0.000 & 0.000 & 0.054 & 0.000 & 0.000\end{array}$

$\begin{array}{llllllll}\mathrm{H} & 0.033 & 0.091 & 0.068 & 0.065 & 0.071 & 0.023\end{array}$

$\begin{array}{lllllll}\mathrm{I} & 0.000 & 0.000 & 0.011 & 0.000 & 0.014 & 0.011\end{array}$

$\begin{array}{lllllll}\mathrm{J} & 0.000 & 0.000 & 0.023 & 0.011 & 0.000 & 0.000\end{array}$

$\begin{array}{llllllll}P G M & (\mathrm{~N}) & 45 & 39 & 44 & 46 & 34 & 45\end{array}$

$\begin{array}{lllllll}\text { A } & 0.000 & 0.000 & 0.000 & 0.000 & 0.015 & 0.000\end{array}$

$\begin{array}{lllllll}\text { B } & 0.011 & 0.013 & 0.000 & 0.011 & 0.044 & 0.000\end{array}$

$\begin{array}{llllllll}\text { C } & 0.067 & 0.051 & 0.034 & 0.033 & 0.059 & 0.044\end{array}$

$\begin{array}{lllllll}\text { D } & 0.322 & 0.359 & 0.398 & 0.424 & 0.441 & 0.367\end{array}$

$\begin{array}{lllllll}\text { E } & 0.000 & 0.000 & 0.000 & 0.022 & 0.000 & 0.011\end{array}$

$\begin{array}{lllllll}\text { F } & 0.567 & 0.538 & 0.432 & 0.435 & 0.412 & 0.533\end{array}$

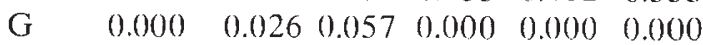

$\begin{array}{lllllll}\mathrm{H} & 0.033 & 0.013 & 0.068 & 0.076 & 0.029 & 0.044\end{array}$

I $\quad 0.000 \quad 0.0000 .011 \quad 0.000 \quad 0.000 \quad 0.000$

'Allele could not be completely resolved. It consists of several electromorphs with a continuous range of mobilities. 